\title{
Review of the biology of plant psyllid (Cacopsylla pruni, Scopoli 1763), and its role in the spreading of European stone fruit yellows, ESFY-phytoplasma with Hungarian data
}

\author{
Dominika Bodnár - Kitti Csüllög - Gábor Tarcali \\ University of Debrecen, Faculty of Agricultural and Food Sciences and Environmental Management, \\ Department of Plant Protection, Debrecen \\ bodnar.dominika@agr.unideb.hu
}

\begin{abstract}
SUMMARY
The European stone fruit yellows (ESFY) phytoplasma disease caused by pathogen 'Ca. Phytoplasma prunorum' induces serious damages in cherry, sour cherry, peach, and apricot orchards mostly in Europe. Its known vector is the plum psyllid (Cacopsylla pruni). Many articles report on the biology (morphology, taxonomy, life cycle etc.) and the method of transmission of the pathogen by the vector, and the possibilities of their control. This paper reviews our knowledge about the vector, and summarises the results of an inland research carried out in a northeastern Hungarian apricot orchards. Our goal was to show some important data for the farmers or anyone who is interested in this disease and its vector. And give some known method that we can protect our orchards against them to prevent the appearance of the disease. As the psyllid that became infected with the pathogen can hold its infectionous capacity during their lifetime, it is very important to have enough knowledge about their lifecycle, that we can determine the right time and method to control them. We also have to know how to identify them; therefore, this paper lists several important data which can be helpful. The most important keys of identification are their wing color, which dark borwn in the apex and brown is in the remaining part of the forewing. The length of the antennae is also an important factor, since other genuse's species have longer antennae than twice the width of the head. C. pruni has as long antennae as twice the width of the head. They return to Prunus species in early spring and we have to protect our orhards in this period against them. We have to use preparations with a knock down effect on them to prevent the inoculation of the pathogen into the trees in our orchards.
\end{abstract}

Keywords: ESFY, plum psyllid, vector

\section{INTRODUCTION}

The phytoplasma diseases cause enormous damage in fruit orchards around the world. Particularly, the Grapevine Flavescence dorée, FD (Szalárdi et al. 2014 ab) in grapevine orchards and the European stone fruit yellows (ESFY) cause increasing damages in Hungary in stone fruit orchards, especially in apricot plantations. The known vector of this disease is the plum psyllid (Cacopsylla pruni, Scopoli 1763) (Carraro et al. 1998). $C$. pruni, naturally infected with ' $C a$. Phytoplasma prunorum' have been found in several European countries: Italy (Carraro et al. 1998), Czech Republic (Fialová et al. 2004), Switzerland (Ramel et al. 2001), Spain (Laviña et al. 2004), Bosnia-Herzegovina (Delic et al. 2005), France (Jarausch et al. 2001), and Hungary (Viczián et al. 2015, Mergenthaler et al. 2017). Until now we do not have detailed data on distribution of this serious vector in Hungary, but their presence was reported in Vas, Somogy, Pest, and Borsod-AbaújZemplén counties (Kiss et al. 2015).

Plum psyllid is a Central-Asian and European species of the genus Cacopsylla (Hemiptera: Psyllidae) (Lautere 1999). It is strictly oligophagus fedding on Prunus spp. and overwintering on conifers (Picea abies, Pinus sylvestris) (Ossiannilson 1992, Hodkinson 2009) and other evergreen plants.

C. pruni could be divided into a complex of two genetic groups (A and B) which have similar biology and morphology but there are some differences between effectiveness of phytoplasma transmission (Sauvion et al. 2007, Peccoud et al. 2013).

Plum psyllid is a serious pest, because both mature and immature males and females can easily transmit phytoplasma in a persistent manner by feeding from the phloem (Carraro et al. 2004a). This is the way how they spread the pathogen of the disease. The disease casuses huge damages in the stone fruit orchards. The most expressive precedent for its size in Hungary is the Borsod-Abaúj-Zemplén County's. In 2010 the infection in the plantations were the hereinafter: in sour cherry $62 \%$, in cherry $30 \%$, in peach $70 \%$ and in apricot $84 \%$.

The aim of this rewiev arcticle is to give important informations about the vector since one of the ways to protect our plantatuons against the pathogen is to protection against the plum psyllids. Also important way the use of healthy mother spawn, but there is no guarantee for the health of them. As we can not cure the infected trees we have to protect our orchards against the plum psyllids. Our goal was to give some important information about the morphology of the psyllid that farmers can easily identify them, also give important datas about their life cycle to better understand their habits and show informations about the ways that we can protect our orchards against them.

\section{MATHERIAL AND METHODS}

During the studies and tiral experiments to better understanding the ESFY disease and the pathogen ( $\mathrm{Ca}$. Phytoplasma prunorum') or the vector (Cacopsylla pruni) there are many methods for the implementation of the studies. For sampling beating tray, sweep netting (Mergenthaler et al. 2017), yellow sticky traps (Paleskić et al. 2017) or jar glasses filled with concentrated etanol can be used (Bodnár et al. 2017) for the smapling of $C$. pruni. 
Most of the morphological studies are carried out with SEM (Scanning electron microscopy) or TEM (Transmission electron microscopy) technologies (Drohojowska et al. 2013).

To detect ESFY infection of Cacopsylla pruni usually PCR, nested PCR or real time PCR methods are used (Carraro et al. 1998, Carraro et al. 2001, Carraro et al. 2004ab, Thébaud et al. 2008, Marcone et al. 2010, Peccaud et al. 2013, Viczián et al. 2015, Bodnár et al. 2017, Mergenthaler et al. 2017).

In a study at 2016 at the region of Boldogkőváralja to investigate the possible swarming routes of Cacopsylla pruni, the host plants and the possible place of overwintering according to the literature were considered. The swarming routes were represented with the help of a satellite map (Picture 1). On the map, places were linked with a straight line which were covered by the host plants, or an apricot orchard. The shortest lines were chosen for investigation place, and observations were obtained along these lines. 4 places were also chosen to capture psyllids. These places were two apricot orchards, a hedge with bushes of blackthorn (Prunus spinosa) near the brook, and also a hedge which was an unused fruit orchard which contained plum, apricot and also blackthorn (Bodnár et al. 2017). To investigate different behaviours associated with weather conditions, and also some other which were not associated with it, the same 4 places were chosen as the place of the captures (Bodnár et al. 2017).

\section{Picture 1: The chosen swarming routs and capture places at the study 2016}

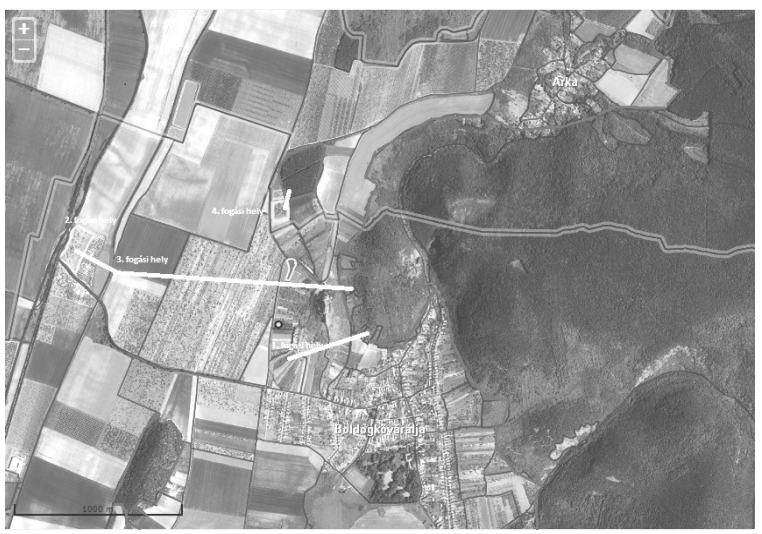

During this study, Cacopsylla pruni individuals were sampled among the swarming routs, and some individuals were captured with the help of jar glasses which contained ethanol for further studying. During the laboratory tests none of them proved phytoplasma carrier. More detailed information about this study can be found in the arcticle of Bodnár et al. (2017).

\section{RESULTS AND DISCUSSION}

\section{Morphology of Cacopsylla pruni}

Many articles reports on the morphology of $C$. pruni (Crawford 1914, Weber 1929, Klimaszewski 1975, Loginova 1978, Ouvard 2002, Ouvard et al.
2002, Buckhardt and Lauterer 2009, Drohojowska 2009ab, Buckhardt 2010, Ripka 2010, Drohojowska et al. 2013). In this section I would like to describe only the main characters. These characters are specific to the $C$. pruni and fundamentally impress to differenciate species of Cacopsylla genus.

Their body is elongated, and dorso-ventrally flattened. The color of the adults is changing through their lifecycle. At first they are light yellow, then they became orange, and in late winter they have brownish black, almost black color (Buckhardt and Lauterer 2009). Males are 2.25-2.71 mm, while females are 2.62-2.95 mm long (Ripka 2010). Membranous forewings cover the swollen abdomen like a roof in a resting position. The forewings are longer than $3 \mathrm{~mm}$, first they are brown at apex, then becoming completely brown. This character of the forewing is important because in the case of other Cacopsylla species $(C$. crataegi, etc), they do not have this twocolored wing color (Picture 2). In the case of $C$. crataegi this character difference is important as they usually move and show overwintering in the same places.

Picture 2: Forewing of $C$. crataegi and $C$. pruni

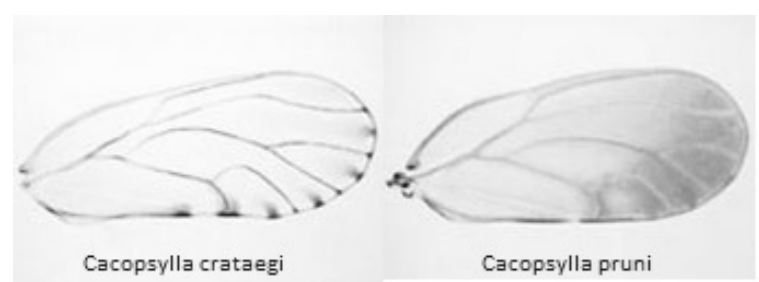

The forewing is weakly widening towards the apical third. Perostigma is long with partly subparallel margins. The surface spinules are densely and irregularly spaced. The veins have the same color as the membrane of the wing (Buckhardt and Lauterer 2009).

The antennaes are shorter than $1.75 \mathrm{~mm}$, their cross-section is circular with only a few sparese setae (usually 10 segments). The length of the antennae of Cacopsylla genera is shorter than twice the head width (Buckhardt 2010). This character also important since the other genus' species in Psyllidae family there are longer antennae than twice the head width (Psylla, Livilla genuses etc).

The number of spurs on the metabasitarsus (basal segment of the tarsus of hind leg) is 2 (Picture 3 ). The number of apical spurs on metatibia is 5, they are strongly sclerotised (Buckhardt 2010). These characters are also important since in the other genuses of the Psyllidae there are different number spurs on their legs (Cacopsylla genus: 2 and 5, Chamaepsylla genus: 2 and 4, Psylla genus: 2 and 5-8 etc). 
Picture 3: The hind leg of Cacopsylla genus

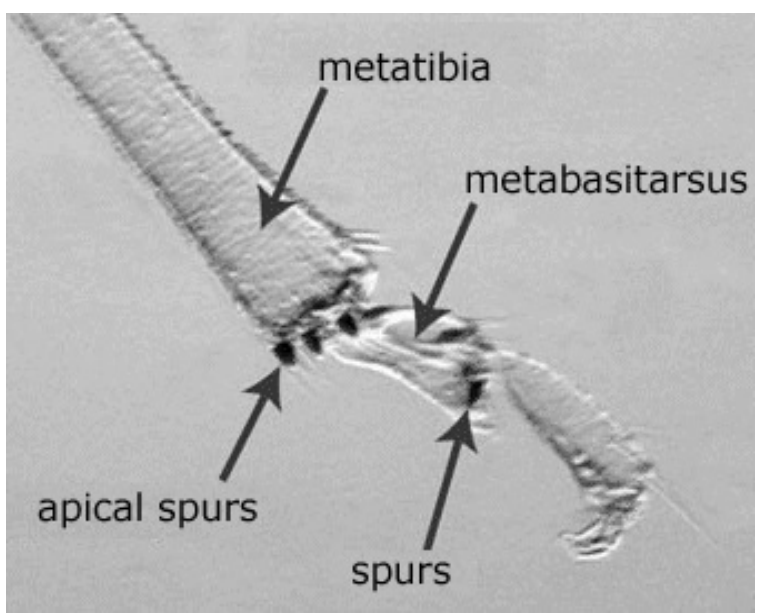

Paramere (paired structure attached to the male subgenital plate used during copulation to hold female terminalia) is lamellar, evenly tapering to apex which forms a single tooth-like sclerotized process, which is curved anteriad. Distal segment of aedegus with hookshaped apical dilatation (Buckhardt and Lauterer 2009).

The female terminalia is moderately long, cuneiform; dorsal margin of proctiger concave, apical part forming narrow process, apex subacute; ventral margin of subgenital plate weekly curved (Buckhardt and Lauterer 2009). Valvula (part of the female ovipositor used to lay eggs) developed from the $9^{\text {th }}$ segmentum abdominale (Buckhardt 2010). The apical part of the subgenital plate of the males are offset (Buckhardt 2010). These characters also specific to identificate $C$. pruni and C. crataegi (Picture 4).

The most important characters that we have respect for during the trial experiments to identify $C$. pruni are the following: the color of the wings, the length of the antennae, and the shape of the genital organs if we can see that with the help of a loupe or a macro objective.

\section{Picture 4: Genital organs of $\boldsymbol{C}$. pruni and $\boldsymbol{C}$. crataegi male and female}

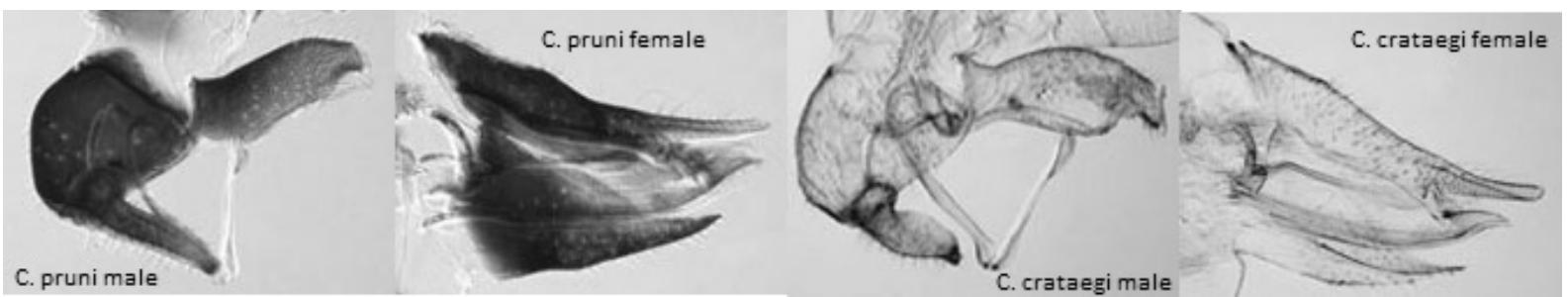

\section{Lyfe cycle of Cacopsylla pruni}

Against the literature about the morphology of $C$. pruni, only scarce information is avialable about their life cycle. This European and Middle-Asiatic pest is univoltine irrespectively of the location. In early spring (Marc-April) the matured (dark-winged) imagoes overwintered on conifers start the cycle, breed and lay eggs on blackthorn (Prunus spinosa), then continue feeding flying from plant to plant (bot hon Prunus spinosa and on other Prunus species, e.g. on apricot). Larvae hatching from the eggs have five larval instars and then the immature (light-colored) adults leave the Prunus spp. at early summer. During the rest of the vegetation period they reported mainly on conifers (Hodkinson et al. 1979, Ossianilson 1992, Lauterer 1999, Thébaud et al. 2009). Many overwintered individuals were collected from Abies normandiana subsp. bornmulleriana and Pinus spp. (Serçe et al. 2011). According to Thébaud et al. (2009) the density of $C$. pruni on conifers was 8 to 80 times lower if there no blackhorn in the near places.

Thébaud et al. (2009) could not find evidence that suggest that $C$. pruni might overwinter on $P$. spinosa bushes contrasting Lautherer (1999) who proved it in the Czech Republic. There are no evidence for a similar occurrence in Hungary. Thébaud et al. (2009) also found that ,captive imagoes die in the greenhouse in the same time when in nature the new adults leave the primary hosts". This period at early summer corresponded to a sharp drop of $C$. pruni population density on Prunus spp.

According to Thébaud et al. (2009) in Southeastern France migration of $C$. pruni passes anyway between Prunus spp. and conifers even they are several kilometers from each other. This long term migration is helped by the dominant winds blowing from the sea toward the mountains in the summer and the opposite direction in the spring. However, in Northern Europe, there is no mention about the fact that $C$. pruni prefers overwintering sites located at higher altitude; therefore, this feature might be an adaptation to warmer summers, increasing survival until the next breeding season through a reduction in the number of degreedays. If host alternation happens between closely located Prunus spp. and conifers, the disease should spread locally; more generally, local secondary spread of the disease might occur where different environtmental conditions prevail.

From the beginning of May, females lay their eggs on both sides and/or petioles of leaves. At the end of May, the larvae of the new generation appear, and the adults swarm in early June, but it is noteworthy that even in late June can be collected overwintered specimens. There are not carried out study about the further life of what long their life exactly. At the end of June the 
swarm reach their peak but adults of new generation fly until the beginning of July. From August, the number of individuals around the Prunus ssp. trees and shrubs suddenly drop due to migration to the sheltering conifers (Ripka 2010).

During the summer dormancy (parapauza) the development of fat bodies in imagoes in most cases goes before the development of genital organs (Lauterer 1999). However sometimes mating occurs during the summer dormancy, but in this case the fertilization fails. The normal period of mating and fertilization is the early spring (April) (Lauterer 1999, Ripka 2010) (Picture 5).

Picture 5: Life cycle of Cacopsylla pruni with some important period of the transmissional cycle

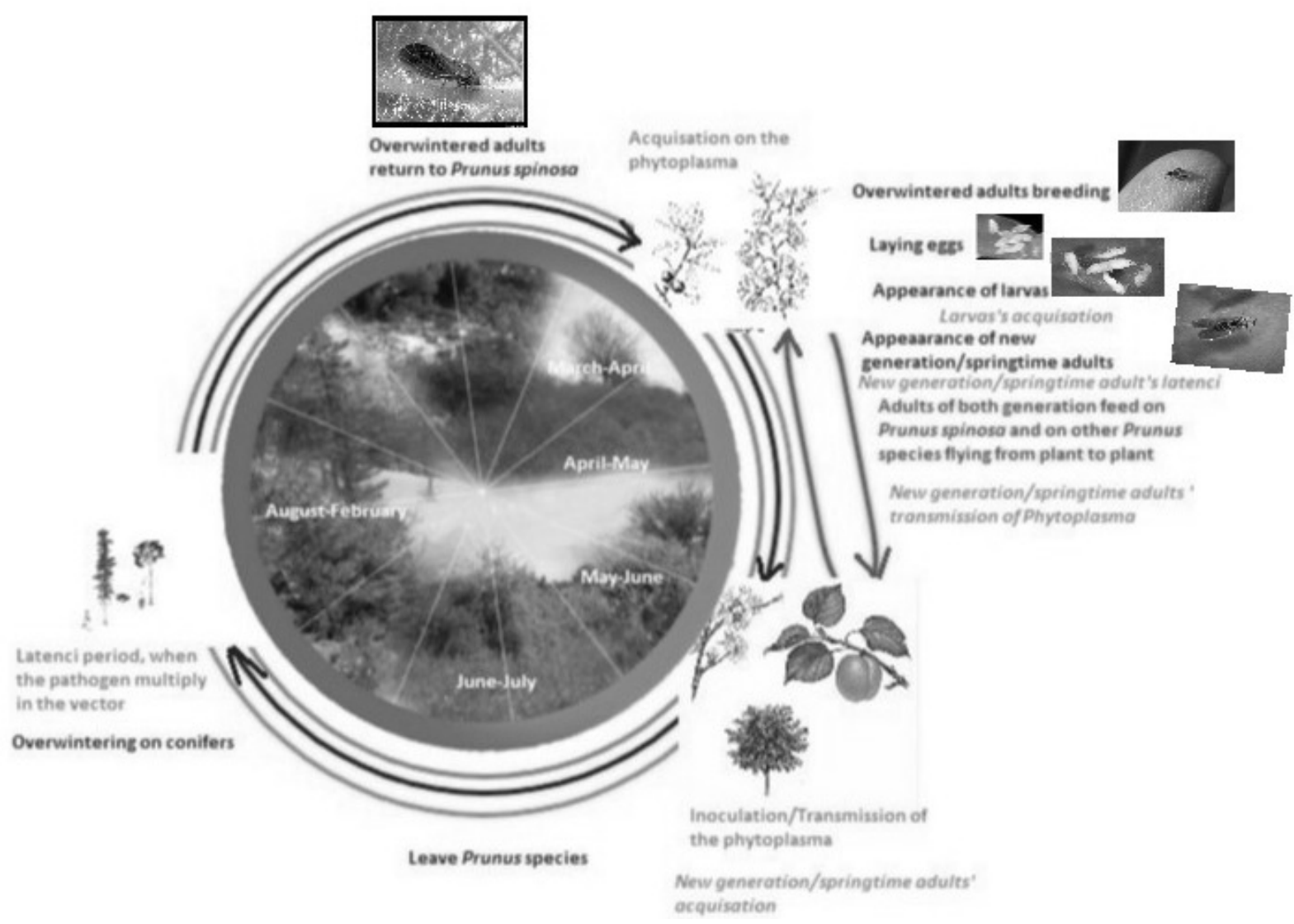

The life cycle of $C$. pruni still leave some question that is worthy of further examination. For example, how it is possible for overwintered adults (dark winged) to live so long? Is it possible that the pathogen has an influence on their life length? It can be an interesting study area in the future.

\section{Transmission of the pathogen by Cacopsylla pruni}

' $\mathrm{Ca}$. Phytoplasma prunorum' the pathogen of ESFY-phytoplasma is specially transmitted by Cacopsylla pruni (Scopoli) (Carraro et al. 1998, Jarausch et al. 2001). The natural transmission period is as long as the vector is present on Prunus species (Carraro et al. 2004a). Studies in Italy showed that both overwintered adults and imagoes of new generation are able to transmit the pathogen to healthy plants. The overwintered imagoes keep their infection ability until the subsequent spring and further to end of their life (Carraro et al. 2001, 2004a). In experimental transmission trials, a minimum acquisition access period
(AAP) between 2 and 4 days, a minimum latent period of 2-3 weeks and a minimum inoculation period of 1-2 days, could be defined. $C$. pruni had acquired the agent in April-May could transmit it one month later (Carraro et al. 2004a). It was also shown that the psyllids transmitted the pathogen in a persistent manner (Carraro et al. 2001, 2004a). There are no information if the phytoplasma can make difference in the mortality or egg laying in the case of Cacopsylla pruni.

Jarausch et al. (2007ab, 2008) found that the vector capacity of both overwintered and springtime adults (adults of new generation in the given year) proved to be lower than that described by Carraro et al. (2001, 2004a). In springtime adults also show lower infestation and transmission rates than in overwintered adults in France during transmissional trials by Carraro et al. (2001, 2004a) and Thébaud et al. (2008). According to Carraro et al (2004a), both the number of phytoplasma carrier insects and the rate of successful transmission were high among the first reimmigrant adults, but 
among the overwintered individuals the proportion of phytoplasma carriers was significantly higher than in the springtime adults. Beyond that the infection ability of the new generation was very low and significantly differed from that could be measured in case of overwintered reimmigrants. In case of young springtime adults the transmittion of the ESFY-phytoplasma was successful only if high number of carrier individuals (10 20 per plant) was used in the investigation (Carraro et al. 2004a).

' $\mathrm{Ca}$. Phytoplasma prunorum' multiplies in both immature and mature vectors. The full acquisationlatency-inoculation sequence nedd relatively long period, thus it can be completed only in very few immature adults before they leave Prunus hosts or die. Contrary, after the winter inoculation priodspend on conifers the vectors can transmit the pathogen very efficiently without additional acquisition in sprigtime from Prunus ssp. (Thébaud et al. 2009). The 8-months long effective latency (the delay between pathogen acquisition and first inoculation by an individual vector in field conditions) of the $C$. pruni, is unique among the known vector-borne diseases; it is more than three times long than in case of the other phytoplasmas (Hogenhout et al. 2008) and for viruses (Nault et al. 1989).

It was also shown that the ESFY agent multiplied in its vector after acquisaition by the new generation also during overwintering, therefore it is transmitted in a persistant-propagative manner (Thébaud at el. 2009). The full acquisation sequence could be accomplished only by a few new generational adults before migrating from Prunus spp. to conifers. In contrast, the most new adults born on infected plants reached their maximum phytoplasma titer only after migrating to conifers in mountanious areas and after a latency of eight months, when migrated back to Prunus spp., had very high transsmission efficiency $(60 \%)$. Thus, secondary spread of the ESFY agent during the growing season appeared to be marginal in comparsion to primary infections which originate from outside a given orchard (Thébaud et al. 2009).

Prunus species are active sources of ESFYphytoplasma inoculum for $C$. pruni (Carraro et al. 2004a). This is not in accordance with that of Jarausch et al. (1999) in France, who did not detect the agent in leaves of Prunus species in spring but only in offseason grown leaves at the end of winter.

A transovarial transmission of the ESFY agent by Cacopsylla pruni was not observed by Carraro et al. (1998). Howewer Tedeschi et al. (2006) found indications for possible transovarial transmission of ' $\mathrm{Ca}$. Phytoplasma prunorum' by the plum psyllid. In their work, different developmental stages of the progeny of infested $C$. pruni females were examined by PCR technology. The pathogen could be detected in eggs, nymphs, and newly emerged adults. Also in transmission experiments using nymphs and newly emerged adults originating from infested females, succesful transmission of the ESFY agent to healthy plum plants was achieved in one case (Tedeschi et al. 2006). The transovarial transmission of the ESFY agent is also possible according to Poggi Pollini et al. (2009) since they detected the pathogen by using the highly sensitive real-time PCR assays from $C$. pruni eggs.

According to Thébaud et al. (2009) immature $C$. pruni acquire ' $C a$. phytoplasma prunorum' while feeding on an infected Prunus sp. (wild or cultivated) and migrate soon after onto conifers located in mountainous regions; C. pruni stays there for 8 months, during which ' $\mathrm{Ca}$. Phytoplasma prunorum' has enough time to multiply and colonize the salivary glands; at the end of winter, C. pruni migrates back to reproduce on Prunus spp., and infects susceptible plants while feeding.

Maier et al. (2013) found that one infectious individual present in an orchard visits and infects several apricot trees.

According to the rewieved information, it is still a question if the psyllid can transovarially transmission the pathogen. Since both that they can and that they can not transmit the pathogen by that way were found as a result of some studies, further examinations need to be carried out.

\section{Host plant preference of Cacopsylla pruni}

The highest vector densities were mainly recorded on wild Prunus spp. such as $P$. spinosa, $P$. cerasifera, $P$. domestica, $P$. salicina. $P$. spinosa and $P$. cerasifera which are reservoirs of the pathogen and the vectors, altough they rarely showed typical symptoms (Carraro et al. 2002, Jarausch et al. 2008).

A multihost multisite field survey and measures of mortality and fecundity in experimental conditions carried out by Carraro et al. (2004b) provided a preference serie of host plants: blackthorn $(P$. spinosa $)>$ plum (Euroepan, Japanese, myrobalan) $>$ apricot (Prunus armeniaca) $>$ peach (Prunus persica) $>$ almond (Prunus amygdalus) $>>$ cherry (Prunus avium), where the ' $>$ ' signs show the magnitude of the difference between preferences.

According to Carraro et al. (1998) during March and April, overwintering adults of $C$. pruni can be mostly captured on 'Myrobalan' basal shoots of apricot (a part of the tree or bush that grows from the roots rather than from the main stem or branches and can form a new tree or bush) and plum trees. Some individuals also occurred on apricot trees, but anyone were found on cherry, peach, pear or apple trees. The first overwintering adults were captured on stone fruit trees at the beginning of March. In May, large populations of nymphs lived especially on 'Myrobalan'.

The overwintered $C$. pruni adults showed a clear preference for $P$. salicina and in decreasing order of importance $P$. domestica, $P$. armeniaca, $P$. persica and other Prunus species (Ermacora et al. 2009).

Cacopsylla pruni have been found but very rarely on other host plants: Malus domestica, Cydonia oblongula and Crataegus spp. (Serçe et al. 2011), which is in contrast with what Carraro et al. (1998) found.

\section{Protection methods agains Cacopsylla pruni}

As we can not cure the trees that are infected by the pathogen, the main method to protect our orchards 
is to prevent the appearance of the disease. One of the methods is the protection against the vector. Since both the overwintered and springtime adults may transmit the pathogen, their control should start in early spring with insecticide treatments against the higly infectious pests arriving from the shelter conifers, (Carraro et al. 1998, 2001). A second treatment in the period of egg deposition should prevent the development of a new generation in the orchards (Marcone et al. 2010).

Plant less prefered tree species and in case of prefered host (e.g. apricot) cutting shoots of the myrabalan or plum rootstocks (Thébaud et al. 2009). It may decrease of infection risk and the population density of the insects.

Control of the overwintering generations of $C$. pruni seems to be of fundamental importance (Carraro et al. 2001).

The main goal of insecticide application in orchards is to keep vector populations as low as possible to minimise the pathogen spread. Overwintered $C$. pruni individuals arrive into the orchards from surrounding untreated areas. Therefore, the first tree(s) reached by higly infectious individuals can only be protected by insecticides that not only reduce the vector populations, but also diretcly effect the pathogen transmission. The crucial point in this context is the minimum IAP (inoculation access period) of 1-2 days. Insecticides with a 'knock down' or instant effect acting in less than 1 day would prevent successful inoculation of healthy trees (Paleskić et al. 2017).

Pesticides which cause rapid chemical-induced alternations of the vector feeding behaviour could also influence pathogen transmission as described for plant viruses (Perring et al. 1999).

Field experiments in Italy aiming to control ESFY by insecticides (chlorpyrifos, etofenprox, azadirachtin, malathion, phosalone, rotenone) showed inconclusive results. Impacts of treatments in April and May on disease ratres were only detected in the minority of these tests (Poggi Pollini et al. 2007).

Paleskić et al. (2017) found that the cypermethrin and thiacloprid cause high insect mortality and both products effectively control $C$. pruni in orchards for more than 1 week. In course of their experiments on budding trees they observed interesting effects of Weissanstrich (white trunk paint) on insect mortality. In principle, this product is used to avoid frost damage of stems during winter. They included it in their tests becouse presumably it produces a stable particle film. Previous experiments have demonstrated that particle films reduced settling and oviposition of adult $C$. pyricola and that the insects had difficulty grasping particle film-treated leaves (Puterka et al. 2005). On budding trees thixotrophic white trunk paint caused $90 \%$ mortality within 48 hours. Thixotrophic white trunk paint could, a formulation for a spray application provided, eventually be a sustainable alternative or complement for treatments before bloom (Paleskić et al. 2017). Cypermethrin caused $100 \%$ insect mortality within 2-4 hours, thiacloprid $90-100 \%$ mortality within 24 hours both foliated and on budding trees. On budding trees spinosad led to 70-90\% mortality within 24 hours. On foliated seedlings flonicamid gave 70$100 \%$ mortality within 1 day, while abamectin, spinosad, acetamiprid and spirotetramat reach this efficiency within 72 hours (Paleskić et al. 2017).

Products based on kaolin, parrafin oil, orange oil and extract of fennel oil as active ingredients were tested for their abiltiy to repel the disease vector $C$. pruni from landing and feeding on Prunus armeniaca. In free choice experiments all products showed significant repellency to adults spending 24 hours after start of the test. After 72 hours then their use, fennel extract oil and orange oil lost their effect, wherease plants treated with kaolin or paraffin oil were barely colonized. In no choice experiments kaolin and parrafin oil significantly affected the feeding behaviour. All tested products significantly reduced the number of surviving insects in comparsion to water treated controls (Riedle-Bauer et al. 2011).

The natural enemies of the $C$. pruni are the larvae of ladybugs (Coleoptera: Cocinellidae) and lacewings (Neuroptera: Chrysomelidae), the hoverfly (Diptera: Syrphidae) and the predatory bugs (Hemiptera: Anthocoris spp.).

\section{Cacopsylla pruni in Hungary}

The first Cacopsylla pruni individuals carry European stone fruit yellows (ESFY)-phytoplasma were found in Pest, Somogy and Borsod-AbaújZemplén Counties at 2014. After that in 2015 the infection rate was studied and it was about $14 \%$ (Viczián et al. 2015).

At first time Merganthaler et al. (2017) discussed our knowledge about the distribution of the pest and the disease in Hungary. They studied the occurrence of the phytoplasma in Cacopsylla pruni collected in different parts of Hungary. They carried out investigations from March to May in 2014 on the overwintering poplulation found on Prunus spinosa and on the springtime adults from May to June. The individuals of both studied generations of $C$. pruni carried 'Ca. Phytoplasma prunorum' phytoplasma. The main ratio of the ESFY phytoplasma carrier psyllids was $15 \%$ both in case of males and felames and was slightly higher (16\%) in the case of nymphs. Molecular classification of $C$. pruni individuals by the 'ITS primer set 3' showed that the all studied $C$. pruni belonged to the ' $\mathrm{B}$ ' genetic group (Mergenthaler et al. 2017).

In 2016, Bodnár et al. (2017) made a research in Boldogkőváralja, where the possible swarming routes of the plum psyllid (Cacopsylla pruni) were determined with the help of satellite maps. The host plants and the possible place of overwintering according to the literature were considered (Bodnár et al. 2017). Psyllids were captured with jar glasses containing 90 $\mathrm{V} / \mathrm{V} \%$ ethanol and they were stored in it during the laboratory tests to identify ESFY-phytoplasma from them. None of the captured psyllids carried ESFYphytoplasma. During the samplings different behaviors of psyllids were observed, according to the weather conditions. When the weather was sunny and windless, 
the psyllids always rested on the young shoots and the lower surface of the young leaves exposed to direct sunlight. In the case of windy weather, the psyllids retract to the leaves seam, while during raining they clung to the lower surface of brunches near the ground, to avoid rain drops washing them onto the ground (Bodnár et al. 2017). The other experiment was not affected by weather conditions. The plum psyllids showed a special band like distribution in the apricot plantations. The apricot plantations were about 1700 $\mathrm{m}$ and about $300 \mathrm{~m}$ far from the conifers. These occupied bands was perpenicular to the rows, and was parallel with the lines between the plantations and nearby patches of sheltering conifers (Picture 6). Bands contained both healthy and infected trees showing the symptoms of phytoplasma disease. The bands in the rows of trees infested trees were 1-2 widths in two directions. Therefore, the width of the band was about $20 \mathrm{~m}$. The plum psyllids were present in these bands in high density. The rest of the plantation is not or only rarely found them (Bodnár et al. 2017).

\section{Picture 6: Swarming routs and the special band like distribution} of the psyllids in the apricot plantations

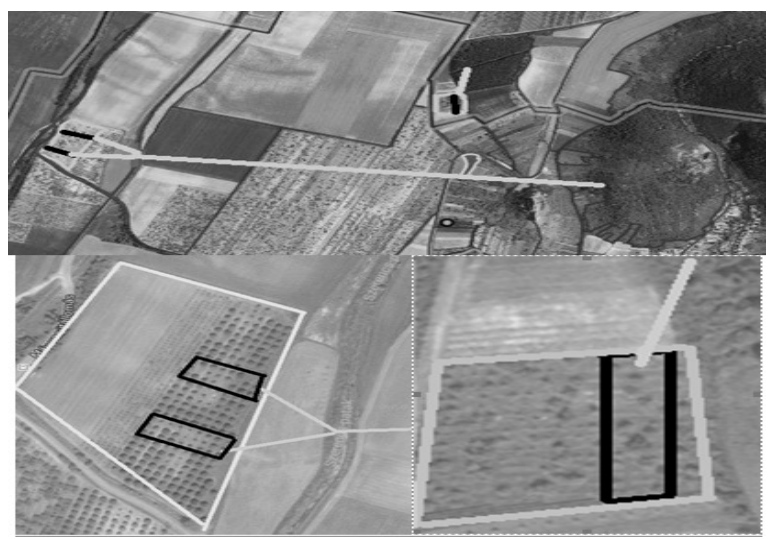

Note: light grey lines sign the swarming routs, black lines sign the band like distribution of the psyllids.

\section{DISCUSSION}

European stone fruit yellows disease cases enormous damages in fruit orchards. The most problems are in apricot in Hungary. As we cannot cure the infected trees we have to prevent to the appearance of the pathogen (' $\mathrm{Ca}$. Phytoplasma prunorum') in our orchards. A method for this is the preotection against its vector, the plum psyllid (Cacopsylla pruni). It is possible to carry out this control in a right way, we can get to know the life cycle, the morphology and the main keys in the method that the vector can transmit the pathogen. Plum psyllids take up the pathogen from the phloem of infected plants and their infectious capacity as long as they live. They inoculate the pathogen to the healthy plant also by feeding on them. The period which is suitable for the inoculation is the time when they are on Prunus species from early spring to July. We can protect our orchards against them with preparations that have a knock down effect. It is important because the inoculation period is 1-2 days. Thus, the knock down preparations can prevent the transmission of the pathogen.

However, this method only works if the pathogen is still not in the orchard. Thus, the use of healthy mother spawn is very important. However, unfortunately, success is not guaranteed, because the checking of the mother spawn to assure that they are aseptic is not solved. For this reason, one has to pay massive attention to control the vector of the pathogen.

\section{ACKNOWLEDGEMENTS}

The publication is supported by the EFOP 3.6.116-2016-00022 project. The project is co-financed by the European Union and the European Social Fund.

\section{REFERENCES}

Bodnár, D.-Tarcali, G. (2017): European stone fruit yellows (ESFY) and its vector (Cacopsylla pruni, Scopoli) presence in BorsodAbaúj-Zemplén County. Georgikon for Agriculture. A multidisciplinary journal in agricultural sciences. 21. 1: 76-91.

Buckhardt, D. (2010): Pictorial key of Central European Cacopsylla species associated with Rosaceae. http://www.psyllidkey.com/ index.html.

Buckhardt, D.-Lauterer, P. (2009): Taxonomy of psyllids (Hemiptera, Psylloidea) associated with apple and stone fruits in Central and Southern Europe. Mitteillungen Der Schweizerischen Entomoloschen Geselleschaft Bulletin De La Societé Entomologique Suisse. 82: 253-257.

Carraro, L.-Ferrini, F.-Ermacora, P.-Loi, N. (2002): role of wild Prunus species in the epidemiology of European stone fruit yellows. Plant Pathology. 51: 513-517.
Carraro, L.-Ferrini, F.-Labonne, G.-Ermacora, P.-Loi, N. (2004b): Transmission of European stone fruit yellows phytoplasma to Prunus species by using vector and graft transmission. Acta Hortic. 657: 449-453

Carraro, L.-Ferrini, F.-Labonne, G.-Ermacora, P.-Loi, N. (2004a): Seasonal infectivity of Cacopsylla pruni, vector of European stone fruit yellows phytoplasma. Ann. Appl. Biol. 144: 191195.

Carraro, L.-Loi, N.-Ermacora, P. (2001): Transmisson characteristics of the European stone fruit yellows phytoplasma and its vector Cacopsylla pruni. European Journal of Plant Pathology. 107: 695-700.

Carraro, L.-Osler, R.-Loi, N.-Ermacora, P.-Refatti, E. (1998): Transmission of European stone fruit yellows phytoplasma by Cacopsylla pruni. J. Plant. Pathol. 80: 233-239. 
Crawford, D. L. (1946): A monograph of the jumping plant-lice or Psyllidae of the new world. Smithsonian Institution. United States National Museum Bulletin. 85: 1-168

Delic, D.-Martini, M.-Ermacora, P.-Carraro L.-Myrta, A. (2005): First report of fruit tree phytoplasmas and their psyllid vectors in Bosnia and Herzegovina. J. Plant. Pathol. 87: 149-150.

Doyle, J. J.-Dojle, J. L. (1990): Isolation of plant DNA from fresh tissue. Focus. 12: 13-15.

Drohojowska, J. (2009a): General information on thorax morphology of selected species of psyllids (Hemiptera, Psylloidea). Monograph aphids and Other Hemipterous Insects. 15: 5-16

Drohojowska, J. (2009b): Sturcture of head and thorax of Livia juncorum (Hemiptera, Psylloidea). Monograph Aphids and Other Hemipterous Insects. 15: 17-30.

Drohojowsky, J.-Kalandyk-Kołodzeijeczky, M.-Simon, E (2013): Thorax morphology of selected species of the genus Cacopsylla (Hemiptera, Psylloidae). [In: Popov, A. et al. (eds.) Advances in Hemipterology.] ZooKeys. 319: 27-35.

Ermacora, P.-Carraro, L.-Ferrini, F.-Martini, M.-Loi, N. (2009): Transmission dynamics of European stone fruit yellows on thirteen Prunus species in controlled conditions. Current status and perspectives of phytoplasma disease research and management. COST Action FA0807. Sitges, Spain. February $1^{\text {st }}$ and $2^{\text {nd }} 2010$. Abstract book of the combined meeting of Work Groups. 1-4: 51.

Fialová, R.-Navrátil, M.-Válová, P.-Lauterer, P.-Kocourek, F.Poncarová-Vorácková, Z. (2004): Epidemiology of European stone fruit yellows phytoplasma in the Czech Republic. Acta Hortic. 657: 483-487.

Heslop-Harrison, G. (1951): Subfamily separation in the Homopterous Psyllidae II. Annals and Magazine of Natural History. 12. 4: 1-35.

Hodkinson, I. D. (2009): Life cycle variation and adaptation in jumping plant lice (Insecta: Hemiptera: Psylloidea) a global synthesis. Journal of Natural History. 43: 65-179.

Hodkinson, I. D.-White, I. M. (1979): Homoptera. Psylloidea. Handbooks for the identification of British Insects. Vol. II Part (5)a. Royal Entomological Society of London. London.

Hogenhout, S. A.-Oshima, K.-El-Desouky, A.-Kakizawa, S.Kingdom, H. N.-Namba, S. (2008): Phytoplasmas: Bacteria that manipulate plants and insects. Mol. Plant Pathol. 9: 403423.

Jarausch, B.-Münhlenz, I.-Fruchs, A.-Lampe, I.-Harzer, U.Jarausch, W. (2007a): Untersuchungen zur Europäischen Steinobstvergilbung (ESFY) in Deutchland. Gesunde Pflanzen. 59: 183-192.

Jarausch, W.-Lansac, M.-Dosba, F. (1999): Seasonal colonisation pattern of European stone fruit yellows phytoplasmas in different Prunus species detected by specific PCR. Journal of Phytopathology. 147: 47-54.

Jarausch, B.-Fuchs, A.-Mühlenz, I.-Lampe, I.-Harzer, U.-Jarausch, W. (2007b): Research on European stone fruit yellows (ESFY) in Germany. Bulletin of Insectology. 60: 389-390.

Jarausch, B.-Mühlenz, I.-Beck, A.-Lampe, I.-Harzer, U.-Jarausch, W. (2008): Epidemiology of European stone fruit yellows in Germany. Acta Horticulturae. 781: 417-422.

Jarausch, W.-Danet, J. L.-Labonne, G.-Dosba, F.-Broquaire, J. M.-Saillard, C.-Garnier, M. (2001): Mapping the spread of apricot chlorotic leaf roll (ACLR) in southern France and implication of Cacopsylla pruni as a vector of European stone fruit yellows (ESFY) phytoplasma. Plant Pathol. 50: 782-790.
Kiss $\quad$ E.-Mergenthaler $\quad$ E.-Kiss $\quad$ B.-Viczián $\quad$ O. (2015): A csonthéjasok európai sárgulása (ESFY) magyarországi terjedésének hátterében álló okok. [In: Horváth J. et al. (szerk.) 61. Növényvédelmi Tudományos Napok.] 2015. február 17-18. Budapest. 60.

Klimaszewki, S. M. (1975): Psyllodea-Kolszki (Insecta: Homoptera). Fauna Polski. Warszawa. 3: 1-294

Lauterer, P (1999): Results of investigations on Hemiptera in Moravia, made by Moravian Museum (Psylloidea 2). Acta Musei Moraviae. Science Biologicae (BRNO). 84: 71-151.

Laviña, A.-Sabaté, J.-García-Chapa, M.-Batlle, A.-Torres, E. (2004): Occurance and epidemiology of European stone fruit yellows phytoplasma in Spain. Acta. Hortic. 657: 489-494.

Loginova, M. M. (1978): Classification of the genus Psylla Geoffr. (Homoptera, Psyllidae). Entomologischeskoe Obozrenie. 57: 808-824.

Maier, C.-Bachinger, K.-Mörtel, J.-Engel, C.-Czipin, L.-RiedleBauer, M. (2013): European Stone Fruit Yellows: A Mark, Release and Recapture Experiment Tracking the Dispersal of its Vector Cacopsylla pruni (Hemiptera: Psyllidae) in a Model Apricot Orchard and Epidemiological Studies in Lower Austria. Journal of Phytopathology. 161: 713-722.

Marcone, C.-Jarausch, B.-Jarausch, W. (2010): Candidatus phytoplasma prunorum, the casual agent of European stone fruit yellows: an overview. Journal of Plant Pathology. 92. 1: 19-34.

Marzachi, C.-Veratti, F.-Bosco, D. (1998): Direct PCR detection of phytoplasmas in experimentally infected insects. Ann. Biol. 133: $45-54$.

Mergenthaler, E.-Viczián, O.-Kiss, B.-Kiss, E. (2017): Survey on the occurance and infection status of Cacopsylla pruni, vector of European stone fruit yellows in Hungary. Bulletin of Insectology. 70. 2: 171-176.

Nault, L. R.-Ammar, E. D. (1989): Leafhopper and planthopper transmission of plant viruses. Annu. Rev. Entomol. 34: 503529.

Ossiannilson, F. (1992): The Phylloidea (Homoptera) of Fennoscandia and Denmark. Fauna Entomologica Scandinavica. 26: $1-347$.

Ouvard, D.-Bourgoin, T.-Campbell, B. C. (2002): Comparative morphological assessment of the psyllid pleuron (Insecta, Hemiptera, Stenorrhyncha). Zoomorphology. 127: 37-47.

Ouvard, D.-Bourgin, T.-Campbell B. C. (2002): Comparative Morphological assessment of the Psyllid Pleuron (Insecta, Hemiptera, Sternorrhyncha). Journal of Morphology. 252: 276-290.

Paleskić, C.-Bachinger, K.-Brader, G.-Kickenweiz, M.-Engel, C.Wurm, L.-Czipin, L.-Riedle-Beuer, M. (2017): Cage and field experiments as basis for the development of control strategies against Cacopsylla pruni, the vector of European stone fruit yellows. Annals of Applied Biology. 170. 3: 1-12.

Peccoud, J.-Labonne, G.-Sauvion, N. (2013): Molecular test to assign individuals within the Cacopsylla pruni complex. PLoS One8: e72454

Perring, T. M.-Greunhagen, N. M.-Farrar, C. A. (1999): Management of plant viral diseases through chemical control of insect vectors. Annual Review of Entomology. 44: 457-481.

Poggi Pollini, C.-Bianchi, L.-Forno, F.-Franchni, S.-Giunchedi, L.-Gobber, M.-Mattedi, L.-Miorelli, P.-Pignatta, D.-Profaizer, D.-Ratti, C. (2007): Investigation on European stone fruit yellows in experimental apricot orchards in the province of Trento (Italy). Bulletin of Insectology. 60: 323-324. 
Poggi Pollini, C.-Forno, F.-Franchini, S.-Gobber, M.-Lanzoni, C.Mattedi, L.-Miorelli, P.-Profaizer, D.-Ratti, C. (2009): Detection and distribution of European stone fruit yellows in apricot cv. Bergeron and epidemiological studies in the province of Trento (Italy). Proceedings of the $21^{\text {st }}$ International Conference on Virus and other Graft Transmissible Diseases of Fruit Crops. Neustadt. 79-80.

Puterka, G. J.-Glenn, D. M.-Pluta, R. C. (2005): Action of Particle Films on the Biology and Behaviour of Pear Psylla (Homoptera: Psyllidae). Journal of Economic Entomology. 98: 2079-2088.

Ramel, M. E.-Gugerli, P.-Bourquin, L.-de Meyer, J.-Schaub, L. (2001): Caractérisation de l'enroulement chlorotique de l'abricotier et détection du phytoplasme ESFY en Suisse romande. Rev. Suisse Vitic. Arboric. Hortic. 33: 279-286.

Riedle-Bauer, M.-Bauer, H.-Mörtel, J. (2011): Effects of possible repellents on feeding and survival of Cacopsylla pruni (Scopoli). Bulletin of Insectology (Supplement). 64: S263-S264.

Ripka G. (2010): Levélbolhák. Agroinform Kiadó. Budapest. 104

Sauvion, N.-Lachenaud, O.-Genson, G.-Rasplus, J. Y.-Labonne, G (2007): Are there several biotypes of Cacopsylla pruni? Bulletins of Insectology. 60: 185-186.

Serçe, C. U.-Yvon, M.-Kaya, K.-Gazel, M.-Cengiz, F. C.Çağlayan, K.-Sauvion, N. (2011): Survey on the presence of Cacopsylla pruni in Turkey: preliminary results. Bulletin of Insectology (Supplement). 64: S145-S146.

Szalárdi T.-Nagy A.-Nagy L.-Tarcali G. (2014a): Az ameriaki szőlőkabóca (Scaphiideus titanus Ball, 1932) Hajdú-Bihar megyei elterjedésének vizsgálata 2014-ben. Georgicon for Agriculture. 1. 19: 84-93.
Szalárdi T.-Nagy A.-Tarcali G. (2014b): Az amerikai szőlőkabóca (Scaphoideus titanus Ball) előfordulásának vizsgálata Debrecenben és a Nyugat-romániai Micskén. Agrártudományi Közlemények. 62: 77-81.

Tedeschi, R.-Ferrato, V.-Rossi, J.-Alma, A. (2006): Possible phytoplasma transovarial transmission in the psyllids Cacopsylla melanoneura and Cacopsylla pruni. Plant Pathology. 55: 18-24.

Thébaud, G.-Ivony, M.-Alary, R.-Sauvion, N.-Labonne, G. (2009): Efficient transmission of 'Candidatus Phytoplasma prunorum' is delayed by eight months due to a long latency in its hostalternating vector. Phytopathlogy. 99: 256-273.

Thébaud, G.-Yvon, M.-Labonne, G.-Alary, R. (2008): European stone fruit yellows: consequences of the life cycle of the vector and the multiplication of the phytoplasma in the insect on the epidemiology of the disease. Acta Horticulturae. 781: 423-428.

Viczián, O.-Mergenthaler, E.-Kiss, E.-Kiss, B. (2015): Monitoring populations of Cacopsylla pruni (Hemiptera: Psyllidae), a vector of European stone fruit yellows in Hungary. $7^{\text {th }}$ European Hemiptera Congress and $9^{\text {th }}$ International Workshop on Leafhoppers and Planthoppers of Economic Ipmortance. Seggau Castle/Graz (Austria) July $19^{\text {th }}-24^{\text {th }}$, 2015. Poster presentation.

Weber, H. (1929): Kopf und Thorax von Psylla mali Scmidberger (Hemiptera-Homoptera). Eine morphogenetische Studie. Zeitschrift für Morpholgie und Ökologie der Tiere. 14: 59-165. 